\title{
MAPPING HEAVY METALS POLLUTION IN URBAN AREA BY USING GIS TECHNIQUES IN DUHOK GOVERNORATE, KURDISTAN REGION OF IRAQ
}

\author{
Ghariba Y. HajI *, Direen J.M. Albeyboni **, SAMi M.A. YousSeF *, NiJyar A.Karim \\ and MOHAMMED Y. FATAH *** \\ *Dept. of Recreation and Ecotourism, Collage of Agriculture Engineering Sciences, \\ University of Duhok, Kurdistan region-Iraq \\ **Dept. of Forestry, Collage of Agriculture Engineering Sciences, University of Duhok, \\ Kurdistan region-Iraq \\ ***General Directorate of Environment, Duhok, Kurdistan region-Iraq
}

(Received: January 14, 2020; Accepted for Publication: February 24, 2020)

\begin{abstract}
In the current century, urbanization is the main reason of the prompt growth in metropolitan areas. These rapid changes in urban form have serious negative consequences on environment quality. Moreover, the air pollution is considered amongst the most significant environmental problems in the world. Recently, GIS tool contribute efficiently in monitoring the spatiotemporal multi-scales. For the present study the inverse distance weight method of interpolation is followed. Therefore, the aim of this study is to find the rate of some detrimental heavy metals $(\mathrm{Pb}, \mathrm{Cd}$, and $\mathrm{Cu})$ then, relying on GIS application the interpolation in different city categories were determined. The results showed control areas characterized by the lowest value of metals, followed by peri-urban areas, and then the highest value comes in highway and city center. Furthermore, the supreme values of heavy metal contamination were found in sites characterized by heavy traffic jam for the most part, by the roadsides. In conclusion, the utmost values of heavy metal contamination were found in sites characterized by heavy traffic jam for the most part, by the roadsides.
\end{abstract}

KEYWORDS: Kurdistan, Heavy metals, GIS application, Environment, spacial modeling, urban area, air pollution.

\section{INTRODUCTION}

$\mathbf{T}$ he rapid growth of cities in the $21 \mathrm{st}$ century is the leading cause of urbanization worldwide (Patel and Burkle, 2012). The evidence of this rapid urbanization can be clearly seen in the incessant development of the transportation systems everywhere (Shinde\&Karjinni, 2005). Conceptually, the urban transport system has been conceived to facilitate the citizen's mobility, and play a key role in the economic, social and cultural activities (Rodrigue et al., 2016). However, these rapid urban changes are having serious negative consequences on environment quality i.e. quality of soil, water, and air (Duh et al., 2008; Huff \&Angeles, 2011; Cassidy et al., 2014). Therefore, the air pollution has become a growing problem in urbanized areas, and recently it's considered amongst the most significant environmental problems in the world. In this context, the urban transportation system is documented as the foremost source of air pollution in various cities. For example, in developing countries the vehicular emission attributes in large measures $(40-80 \%)$ to crisis resulted from air contamination (Mishra \& Pandey, 2011).

Air Pollution is an atmospheric condition with the predominant existence of hazardous substances that are detrimental to human being and animals (Mishra et al., 2019). By way of illustration, the air-borne contaminants degrade the air quality and continuous exposure to unclean air certainly lead to major public human health problems such as wheezing, coughing, cardiopulmonary disease, asthma and bronchitis etc (Yerramilli et al, 2011).Among all air-borne contaminants, the heavy metals are considered of particular concern to urban environment (Sarkar \&Webster, 2017, Rajé et al., 2018). Moreover, the high vehicle traffic was proven to be one of 
the important heavy metals emissions sources (Świetlik et al, 2013; Hu et al, 2018). Among these heavy metals, the lead, zinc and copper are the most common discharged by vehicle traffic, adding up at least $90 \%$ from the overall emitted quantity (Popescu, 2011). Correspondingly, vehicle traffic is in charge of the emission small quantities of some other metals, like cadmium and nickel (United States Office of Air Quality, 2007; Popescu, 2011).

In recent years, there has been an increasing interest in the installation devices / networks for monitoring the urban air quality (Kumar et al., 2016).

This vigorous urban air quality networks often indicates significant temporal and spatial variations, and allow to implement an efficient policy of urban development (Gerdol et al., 2014; Kumar et al., 2016).In this circumstance, the contemporary development of spatial data management like the outline of geographic information systems (GISs) has generated a new era with respect to environmental modelling. Moreover, these GISs are often the contemporary prevailing tool that facilitates connecting nonspatial information to spatial data (Matejicek, 2005). Along with its embedded relational database component, the system contributes in storing, then mapping and analyzing georeferenced data in an organized form (Yerramilli et al,. 2011).

In recent urban environment context, the GIS tools efficiently contribute on the monitoring of the spatiotemporal multi-scales which would play a crucial role in reducing the cost and the time of field surveys. Despite its productive success worldwide in term of urban modeling and management, however, far too little attention has been paid to the uses and application of GIS on Duhok urban environment issues. Furthermore, most research studies have been carried out in small urban areas and/or tended to focus on urban water quality (Mustafa and Noori, 2013), land cover and land change (Mohammed, 2013) or spatial distribution planning of tree species in non-urbanized areas (Habeeb and Mustafa 2014). Concerning the GIS application on the air pollution approaches in Duhok urban areas, Hassan (2012) has evaluated the vehicle exhaust emission effects on the air quality of Duhok city. But, the research has analyzed only the $\mathrm{CO}_{2}$ rate presented in air within 9 locations representing the entire study area. Therefore, the main aim of this study is to determine the rate of some serious heavy metals $(\mathrm{Pb}, \mathrm{Cd}$, and $\mathrm{Cu})$ related to traffic within Duhok City. Moreover, relying on GIS application to show the interpolation in different city categories.

\section{MATERIALS AND METHODS}

\subsection{Study area}

The current research study was carried out in urban areas throughout Duhok city in the north of Kurdistan Region of Iraq (latitudes: $36^{\circ} 49^{\prime} 30^{\prime \prime} \mathrm{N}$ to $36^{\circ} 52^{\prime} 30^{\prime \prime} \mathrm{N}$; longitudes: $42^{\circ} 54^{\prime} 30^{\prime \prime}$ Eto $43^{\circ} 3^{\prime}$ $\left.30^{\prime \prime} \mathrm{E}\right)$. Duhok city is situated on approximately $585 \mathrm{~m}$ above sea level (asl) covering about 39.67 $\mathrm{km}^{2}$ (Mohammed, 2013). Currently, the population of the city is about 1,133,627 inhabitants (NCCIRAQ, 2015) which consists multiethnic communities. Its strategic position at the junction of Iraqi, Syrian and Turkish borders places it at the heart of multi-intercultural interaction (Mustafa et al., 2012). From a climatologically standpoint, Duhok possess a Mediterranean microclimate that's cold and rainy in winter whereas, hot and dry in summer (Youssef et al., 2019). Temperature degrees start to elevate gradually until reaching its highest, up to $\left(37.5^{\circ} \mathrm{C}\right)$ during July. See Figure (1). 


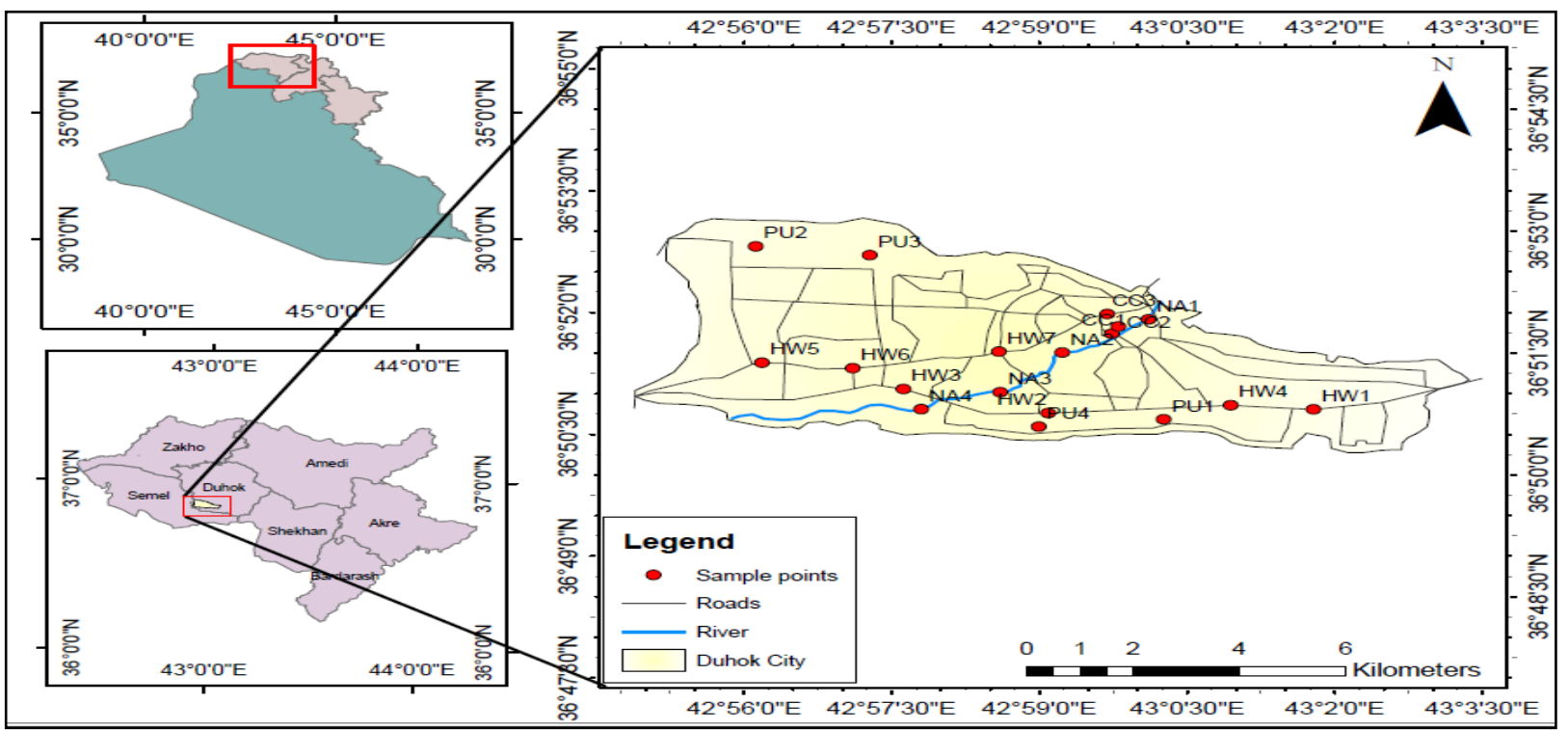

Fig. (1): Location of the Sample points in Duhok city.

\subsection{Selected Tree species}

For this research study, the samples were taken from eighteen locations in Duhok urban areas, from the leaves of three tree species (Pinus brutia, Cupressus sempervirens, and Melia azedarach). Moreover, the locations have been selected according to four categories: i) highway, ii) city center, iii) peri-urban and iv) controlled/ natural area (Albeyboni, 2019). Furthermore, the selected tree species are commonly cultivated in Duhok urban area like other Kurdish cities. These urban tree species were selected on the basis of their availability within all the selected location categories. Besides, the chosen tree species are proven to be of high effectively as bioindicator of pollution within residential areas (El-Hasan et al., 2002, Dogan, et al., 2010, Bozdogan, 2016).

\subsection{Tree samples collection and laboratory analysis for determination of heavy metals bioaccumulation}

During the study eighteen locations has been determined on the Duhok map which represent all urban and Peri-urban areas of the city. They localized as following: four locations were on Shindukha highway, three on Malta highway, four at Peri-urban area, three from the centre of the city and four was taken from controlled areas. To meet the study objectives, leaves samples were taken from three tree species (Pinus brutia, Cupressus sempervirens, and Melia azedarach) at the end of April to the beginning of May. The tree leaves were taken from five branches for each tree species, moreover the selected leaves were from the side of the tree nearest the street.
Samples were kept in plastic bags, and field required information (collection date, location GPS, coordinates (longitude, latitude), habitat notes, etc.) were written on the bags. Then, all samples were taken to the laboratory of the Environment Directorate of Duhok city for analysis. All the samples were documented and numbered according to their environmental conditions as well as their locations. Knowing that for leaves preparation and analyses the protocol of Martens and Lindsay (1990) were followed. Leaves were washed with tap water then with distilled water. After washing, the leaves were placed in the oven at $60{ }^{\circ} \mathrm{C}$ for 48 hours. Thereafter, the dried leaves grinded with grinding machine to soft powder then all the samples were digested and filtered through Whitman No. 42 filter paper and the volume were brought to $50 \mathrm{ml}$ by deionized water. Lead $(\mathrm{Pb})$, Cadmium $(\mathrm{Cd})$ and Copper $(\mathrm{Cu})$ were determined by Atomic Absorption Spectrophotometer (Martens \& Lindsay, 1990).All the gotten data were organized in excel sheets, and the linear regression model was applied to forecast and illustrate the relationship between heavy metals concentrations and the level of traffic intensity.

\subsection{GIS application}

In this study, the data collected from Duhok city and coordinate points by GPS device at

Each location and the latitude and longitude readings were taken at Table (1). All data processing was carried out in ArcGIS version 10.2 ESRI (1999). Inverse Distance Weighting (IDW) interpolation method software used for the 
concentration of each three heavy metals $(\mathrm{Pb}, \mathrm{Cd}$ and $\mathrm{Cu}$ ). When the points are uniformly distributed and the number of elevation points in an area is large the IDW provide a satisfactory results. Also, sample points are implicitly known to be autonomous of each other (Yilmaz \& Hocanli, 2006; Gouri et al., 2018). Generally, interpolation helps to predict the cell values in a pattern format using a given number of sample data. It is a good tool for prediction of unknown values for a given geographic point data which in this study is the concentrations of the three heavy metals i.e. $\mathrm{Pb}, \mathrm{Cd}$ and $\mathrm{Cu}$.

Table (1): coordinate of the sample points in Duhok City

\begin{tabular}{|c|c|c|c|c|c|}
\hline Category & Abbreviation & Longitude & Latitude & Samples & Site description \\
\hline Highway & HW1 & N36 50' 48.390" & E43 01' 47.26" & 3 tree sp. & $\begin{array}{c}\text { Barzan HW, near } \\
\text { Parwar Hotel }\end{array}$ \\
\hline Highway & HW2 & N36 50' 45.605" & E042 59' 05.535" & 3 tree sp. & $\begin{array}{c}\text { Barzan HW near KIU } \\
\text { station - traffic light }\end{array}$ \\
\hline Highway & HW3 & N36 51' 03.359" & E 042 57' $37.246 "$ & 3 tree sp. & $\begin{array}{c}\text { Barzan HW } \\
\text { Near Azadi Rest. }\end{array}$ \\
\hline Highway & HW4 & N36 50' 51.38" & E43 0' 56.79" & 3 tree sp. & $\begin{array}{l}\text { Zakho HW Median } \\
\text { island, near Mazi mall }\end{array}$ \\
\hline Highway & HW5 & N36 51' 22.90" & E042 56' 11.01" & 3 tree sp. & Zakho HW Viking Rest. \\
\hline Highway & HW6 & N36 51' 18.754" & E042 57' 06.320" & 3 tree sp. & $\begin{array}{c}\text { Zakho HW } \\
\text { Automotive industrial } \\
\text { area }\end{array}$ \\
\hline Highway & HW7 & N36 51' 30.97" & E042 58' 35.52" & 3 tree sp. & $\begin{array}{c}\text { Barzan HWCinar Rest. } \\
\text { near traffic light }\end{array}$ \\
\hline City Center & $\mathrm{CC} 1$ & N36 51' 58.689" & E042 59' 41.529" & 3 tree sp. & $\begin{array}{c}\text { Near DHL and Fedex } \\
\text { office }\end{array}$ \\
\hline City Center & CC2 & N36 51' 44.338" & E042 59' 44.276" & 3 tree sp. & Over Nuhedra Bridge \\
\hline City Center & $\mathrm{CC} 3$ & N36 51' 49.529" & E042 59' 48.217" & 3 tree sp. & Near Bourse \\
\hline Peri-urban & Purb1 & N36 50' 41.084" & E043 00' 15.90" & 3 tree sp. & Barzani Park \\
\hline Peri-urban & Purb2 & N36 52' 48.69" & E042 56' 07.268" & 3 tree sp. & Masika (Aram City) \\
\hline Peri-urban & Purb3 & N36 52'42. 305" & E042 57' 16.784" & 3 tree sp. & Behind Davinci institute \\
\hline Peri-urban & Purb4 & N36 50'44.078" & E042 59' 40.74" & 3 tree sp. & $\begin{array}{l}\text { HaylAskari } \\
\text { (Reshavast.) }\end{array}$ \\
\hline Control & Control1 & N36 53' 52.864" & E43 8' 50.763" & P. brutia & Zawita \\
\hline
\end{tabular}




\begin{tabular}{cccccc}
\hline Control & Control2 & N37 00' 06.248" & E043 13' 00.263" & P. brutia & Swaratoka \\
\hline Control & Control3 & N36 52' 19" & E43 7' 34.05" & P. brutia & Bablo \\
\hline Control & Control4 & N36 48' 27.56" & E47 59'37.05 & $\begin{array}{c}\text { C. sempervirens, } \\
\text { M. azedarach }\end{array}$ & Sharya \\
\hline
\end{tabular}

\section{RESULTS \& DISCUSSION}

This paper help to study the evaluation of air pollution within the help of advanced modern technology based study like GIS.ArcGIS spacial analysis model (Version 10.2) within inverse distance weight model was used to interpolate the air pollution mapping. It was used to interpolate the different pollutant concentration to a spatial air mapping. The (IDW) method of interpolation is the favourite geo-statistical technique in air pollution modelling (Jerrett et al., 2005).In the current study, the concentration of three metals $(\mathrm{Cd}, \mathrm{Pb}$ and $\mathrm{Cu})$ for the taken tree species (Pinus brutia, Cupressus sempervirens, and Melia azedarach). The spatial air mappings are clearly founded in the study area as shown in the Figures (2, 3 and 4$)$.

There is a good match between the current and previous studies related to polluted

plants of roadsides with heavy metals, majorly with $\mathrm{Pb}$ and $\mathrm{Cd}$ (Singh et al., 1997; Khan et al.,
2011). In the current study, the concentration of three metals $(\mathrm{Cd}, \mathrm{Pb}$ and $\mathrm{Cu})$ for the taken tree species (Pinus brutia, Cupressus sempervirens, and Melia azedarach), at chosen locations shown in Figures (2,3 and 4). The data in general demonstrated elevated levels in plant leaves with increase in urbanization and denseness. Moreover, the activities of industrial areas and the density of traffic in urban roadsides can be considered as major ins and outs of the heavy metals elevated levels (Celik et al., 2005; Naderizadeh et al., 2016). The values starts from control areas with the lowest value of metals, followed by peri-urban areas, and then the highest value comes which, was found in Highway and City center. Furthermore, the utmost values of heavy metal contamination were found in sites characterized by heavy traffic jam for the most part, by the roadsides. These findings are in agreement with those perceived in earlier studies (Ndiokwere, 1984; Rajéet al., 2018).

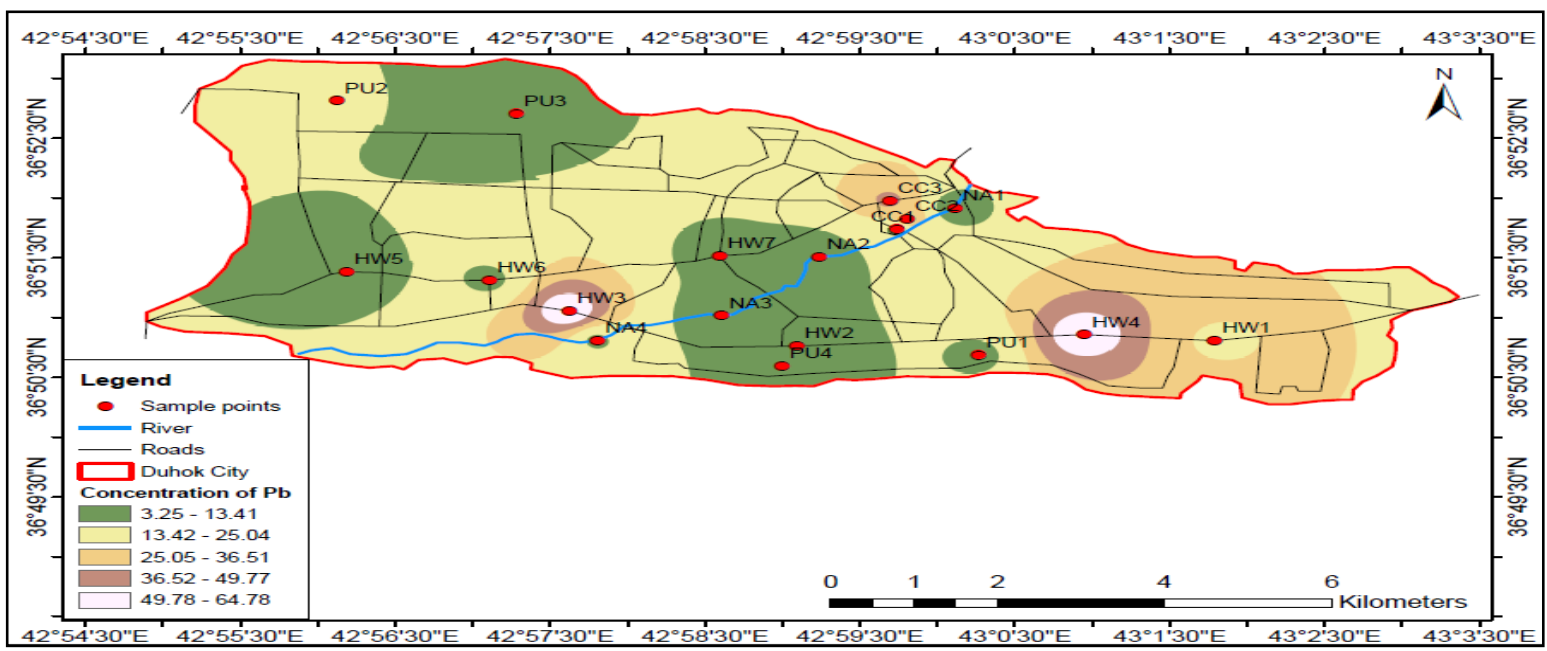

Fig. (2): The concentration of Lead 


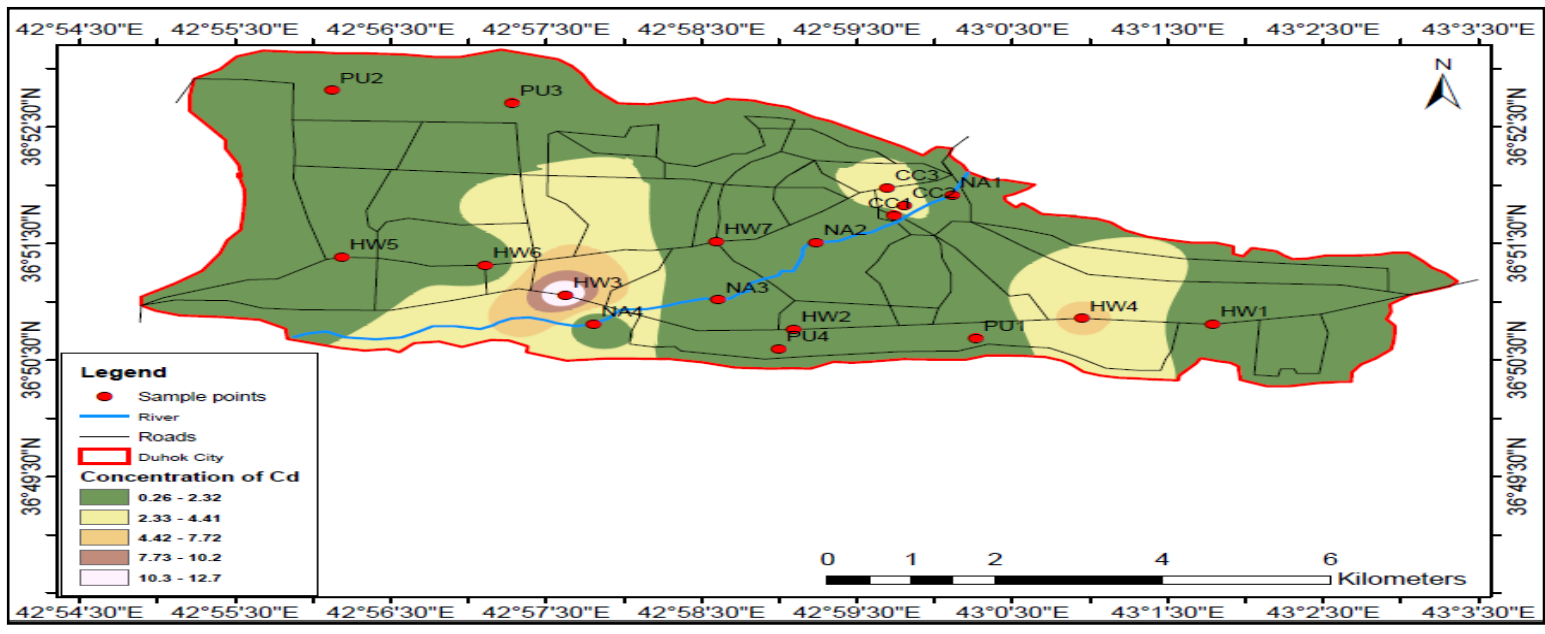

Fig. (3): The concentration of Cadmium

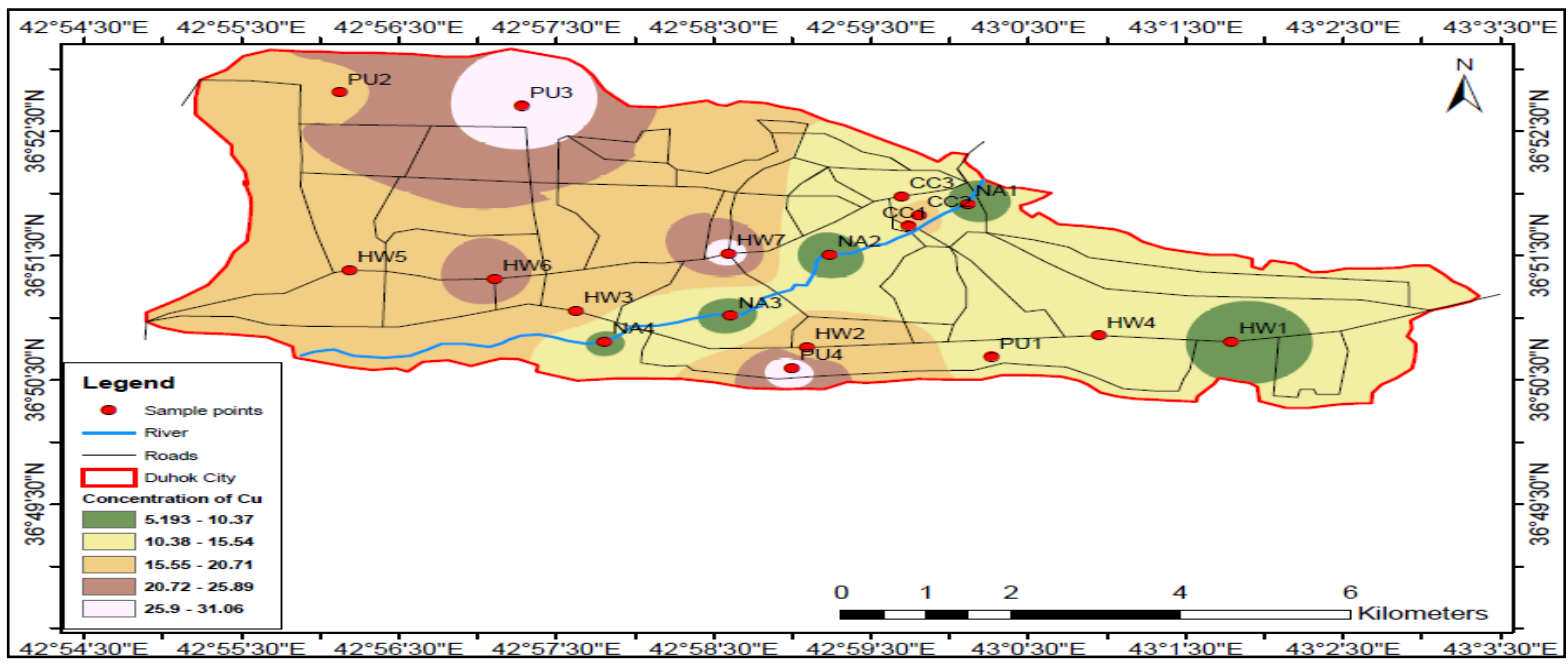

Fig.(4): The concentration of Copper

Lead is of the pollutants that taken up passively by trees, from contaminated air resources (Staszewski et al., 2009). Pb for the most part added to the surrounding environment by reason of aerial deposition (Aksoy et al., 2000; Celik et al., 2005). The outcomes of $\mathrm{Pb}$ concentrations for the selected tree species $(P$. brutia, $C$. semprevirens, and $M$. azedarach), in eighteen locations handing out four categories control, Purb, CC, and HW, are presented in Figures $(5,6.7)$. 
Journal of University of Duhok., Vol. 23, No.1 (Agri. and Vet. Sciences), Pp 51-64, 2020

https://doi.org/10.26682/ajuod.2020.23.1.7

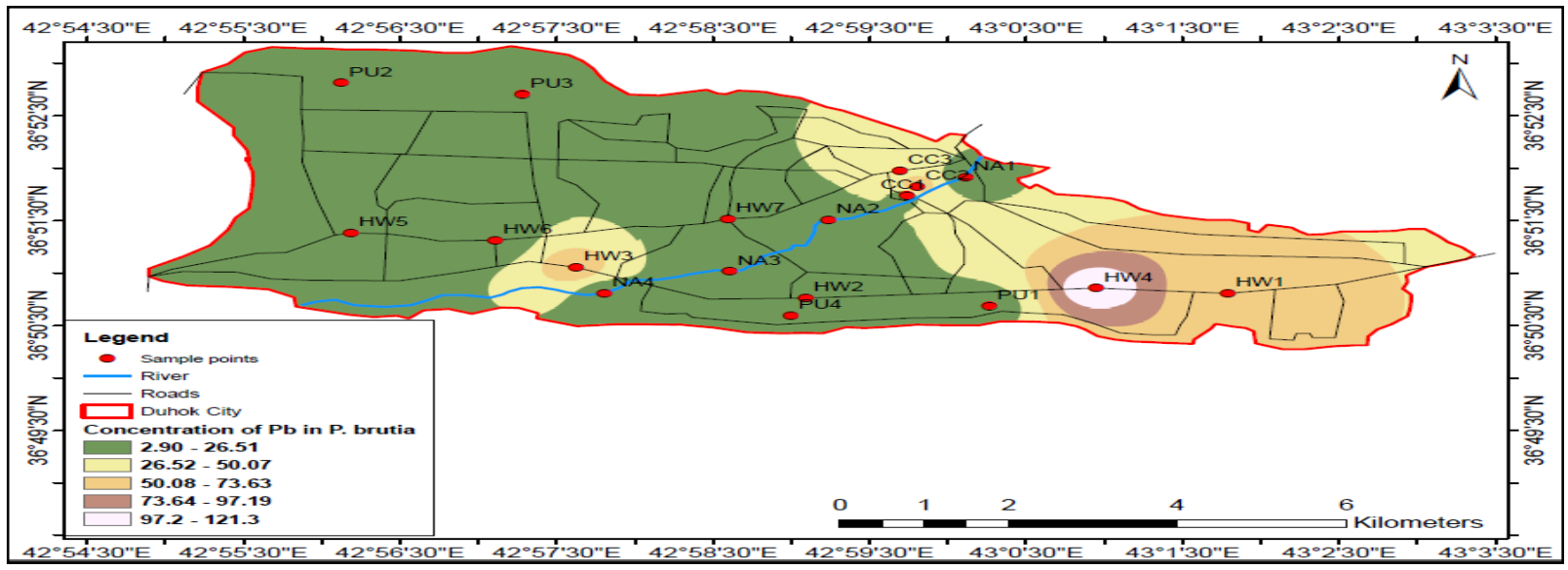

Fig. (5): The concentration of $\mathrm{Pb}$ in $P$. brutia

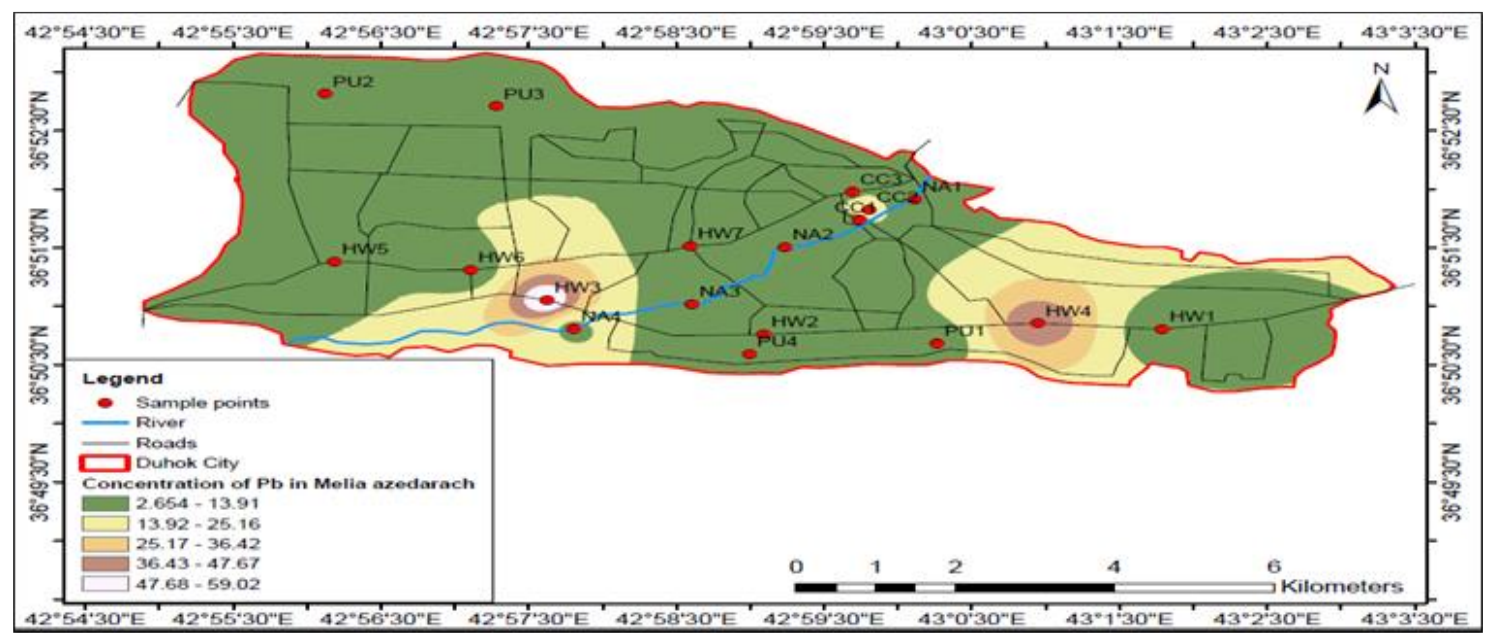

Fig.(6): The concentration of $\mathrm{Pb}$ in $C$. semprevirens 


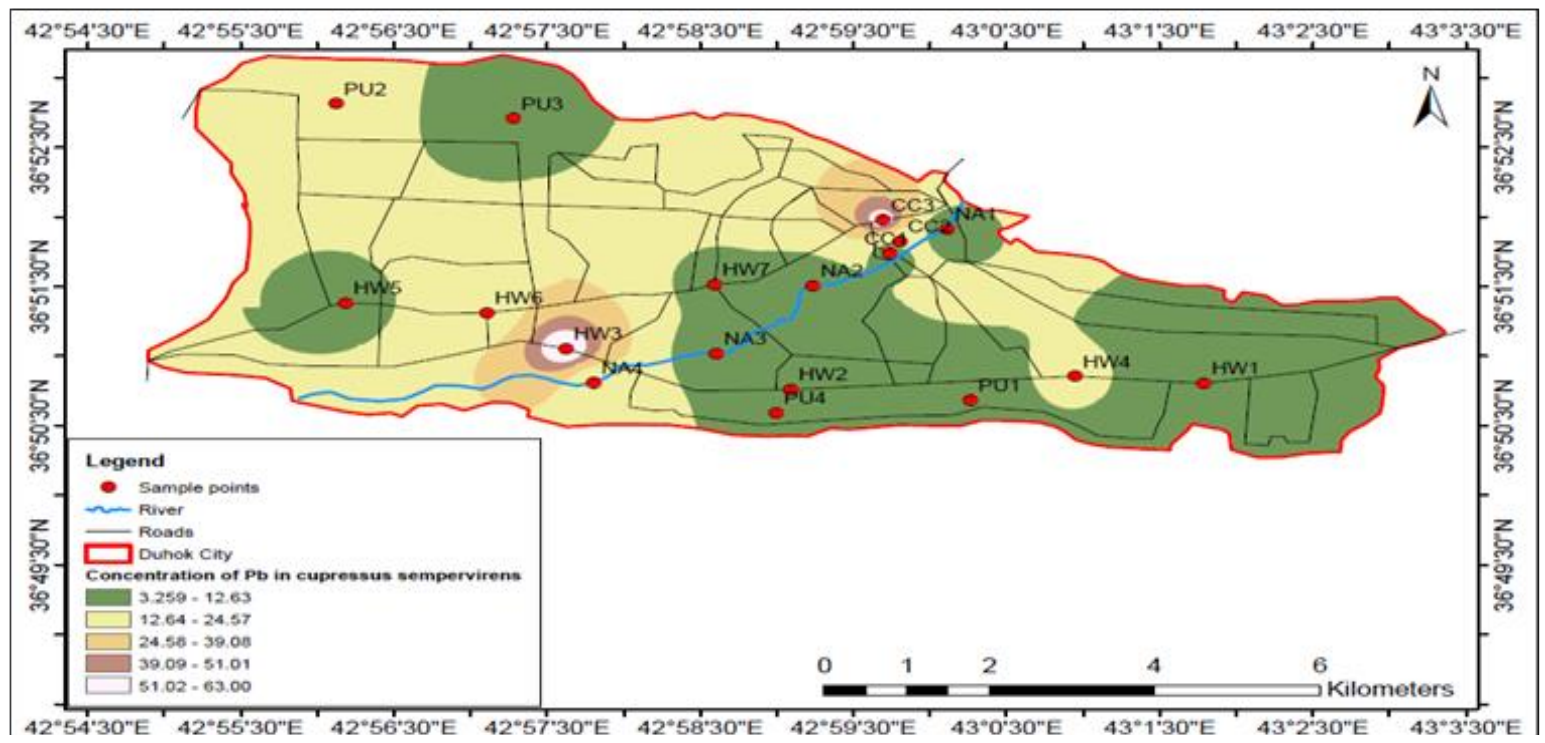

Fig.(7): The concentration of $\mathrm{Pb}$ in $M$. azedarach).

The overall measurement results demonstrate the value of $\mathrm{Pb}$ ranged between 2.65 and $120.75 \mathrm{mg} . \mathrm{kg}^{-1}$ d.wt. The value of $\mathrm{Pb}$ in $P$. brutia for HW, CC, and Purb started from 2.94 up to $120.733 \mathrm{mg} \cdot \mathrm{kg}^{-1}$, despite the fact the control ranged between 3.25 and $5.02 \mathrm{mg} \cdot \mathrm{kg}^{-1}$. Then again, the $\mathrm{Pb}$ in $M$. azedarach fluctuated between
2.65 and $58.95 \mathrm{mg} \cdot \mathrm{kg}^{-1}$, the control was 10.7 mg.kg ${ }^{-1}$. Moreover, the C. sempervirens also displays elevated levels in specific sites, lies in the ranges 4.45 and $62.98 \mathrm{mg} \cdot \mathrm{kg}^{-1}$, and nonetheless for the control rate was 12.497 mg.kg- ${ }^{-1}$.

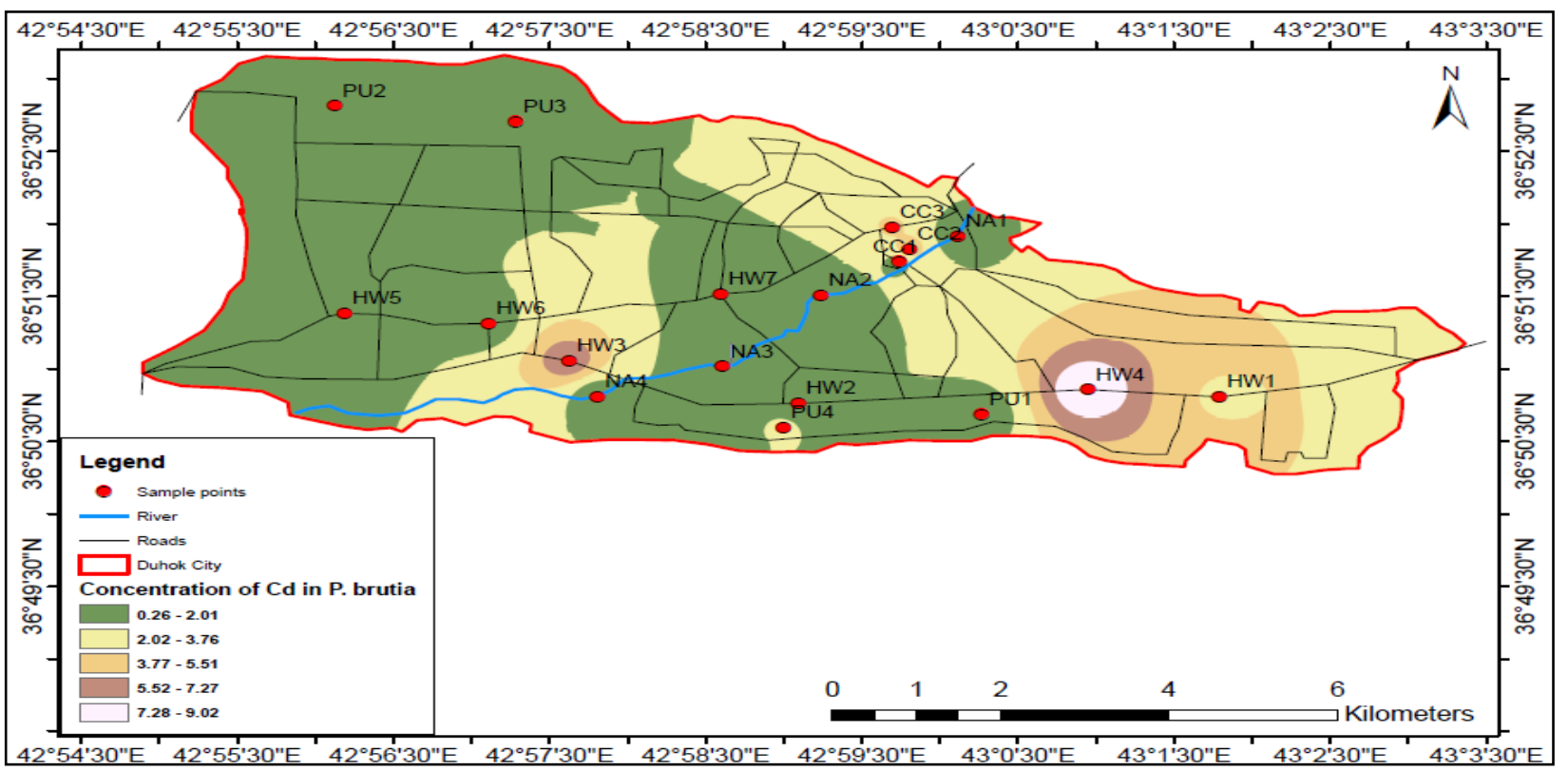

Fig. (8): The concentration of $\mathrm{Cd}$ in $P$. brutia 


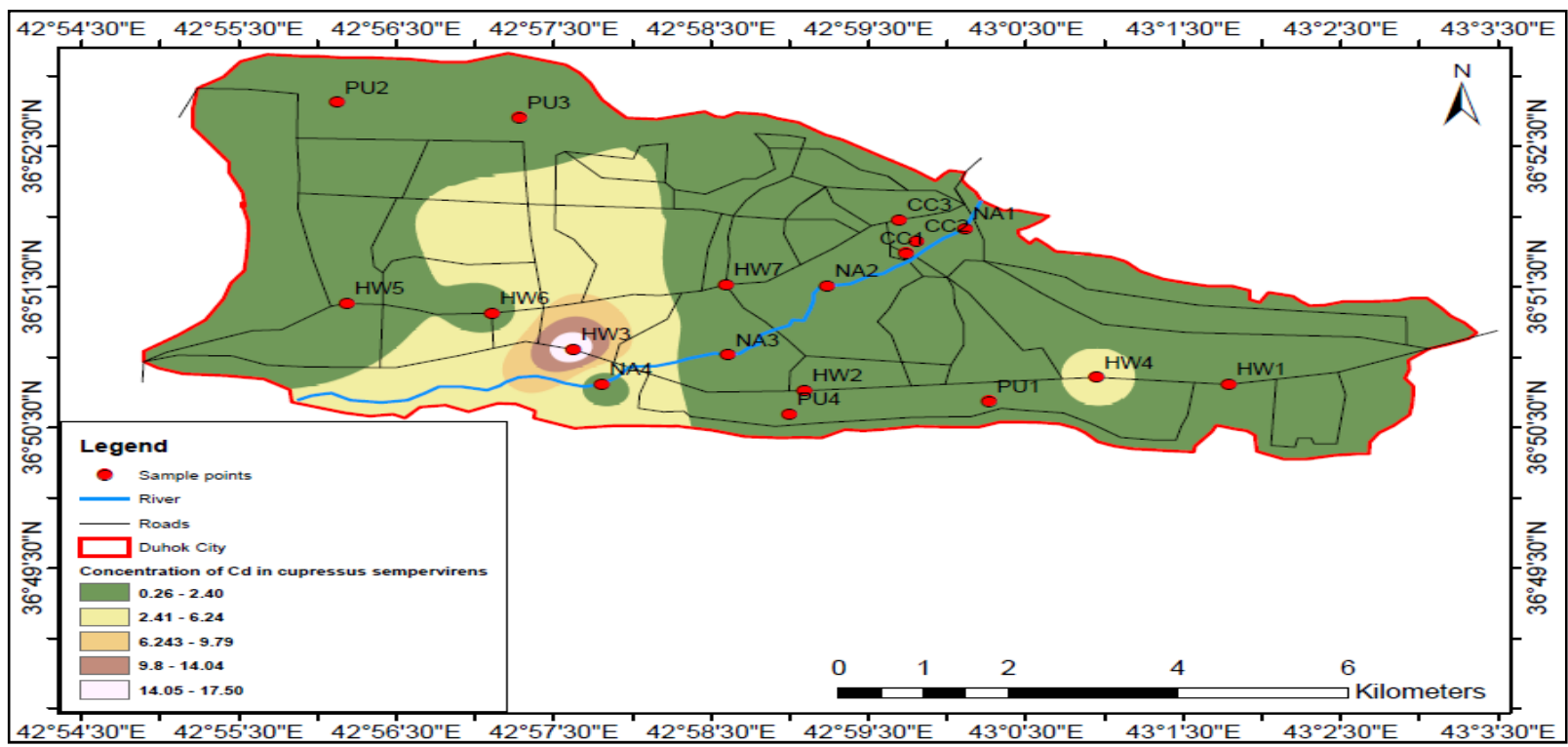

Fig.(9): The concentration of $\mathrm{Cd}$ in $C$. semprevirens

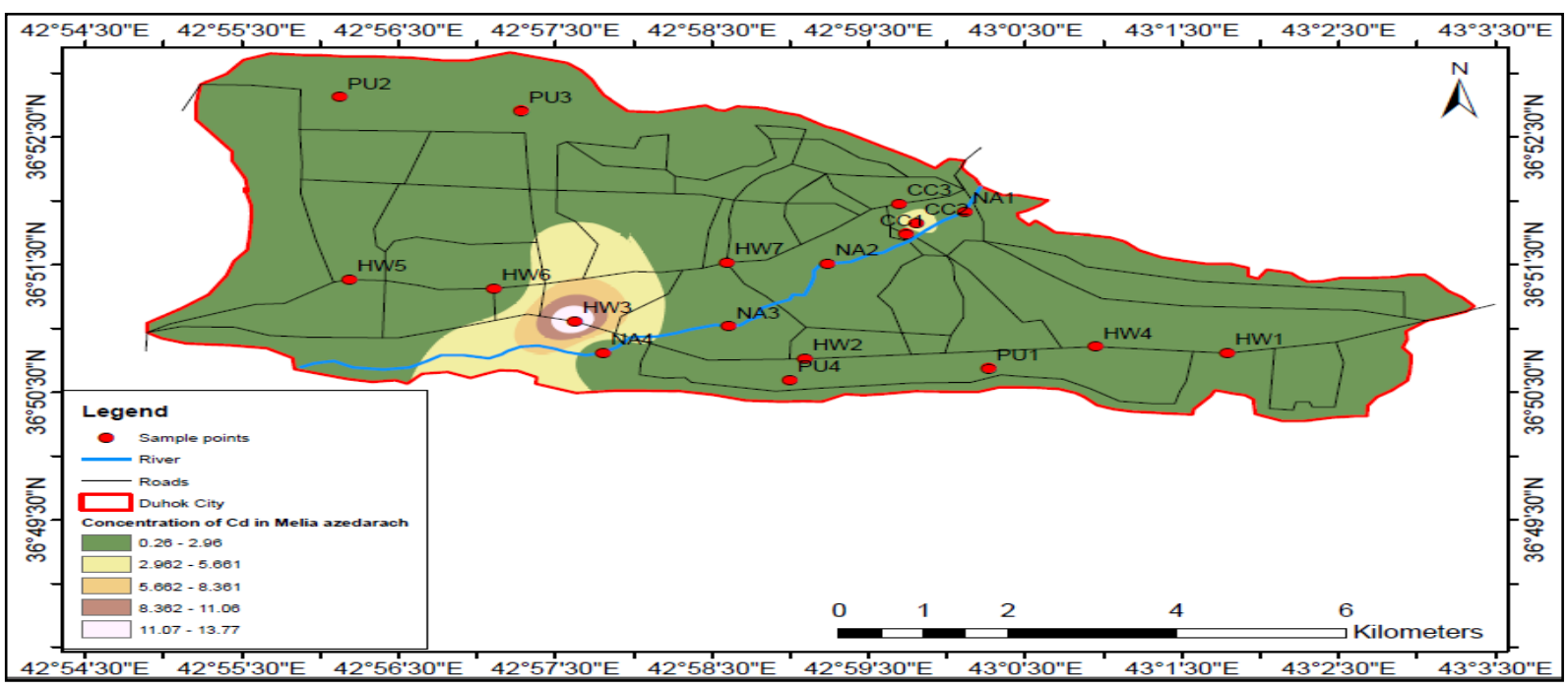

Fig.(10): The concentration of $\mathrm{Cd}$ in M. azedarach.

On the other hand, Cadmium values set between 0.46 and $17.49 \mathrm{mg} \cdot \mathrm{kg}^{-1}$. Besides, both the lowermost and uppermost values found in $C$. sempervirens leaves. Though, in controlled area the range was between 0.26 and 0.81 mg.kg- ${ }^{1}$. Due to (Kabata-Pendias \& Pendias, 2001), the level of $\mathrm{Cd}$ in nearly all the locations considered beyond the safe levels in addition, only in four selected points the rate is within the noxious limit. See Figure (8, 9 and 10). The maximum value of $\mathrm{Cd}$ is found in highway and nearly all the tested tree species are of same efficiency for capturing $\mathrm{Cd}$. Furthermore, the highest value is presented in highway in the surrounding areas to roadside and traffic intensity followed by $\mathrm{CC}$ then the concentration drops substantially at Peri-urban. This decline in the levels of cadmium along with distance from the main roads show that motor vehicle emissions play a noteworthy role of variation in $\mathrm{Cd}$ levels (Bakirdere \&Yaman, 2008). 


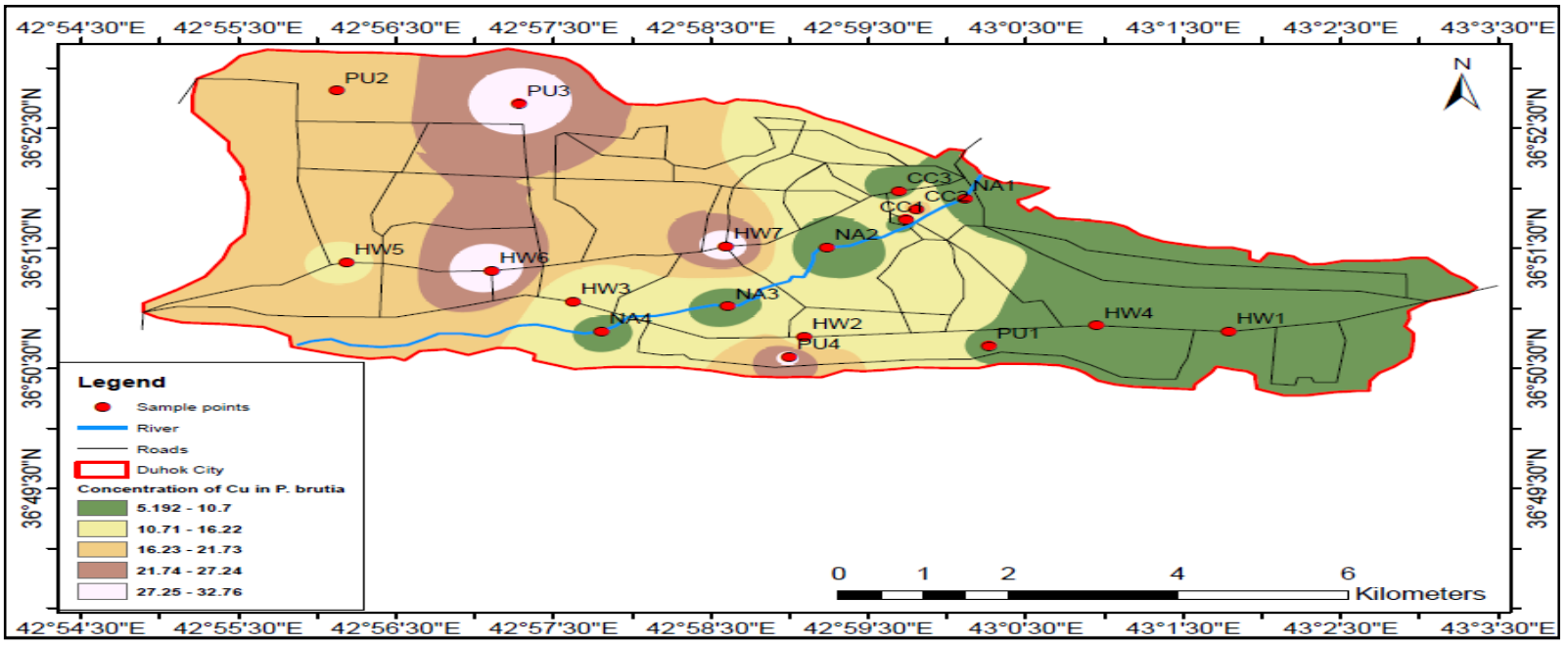

Fig. (11): The concentration of $\mathrm{Cu}$ in P. brutia.

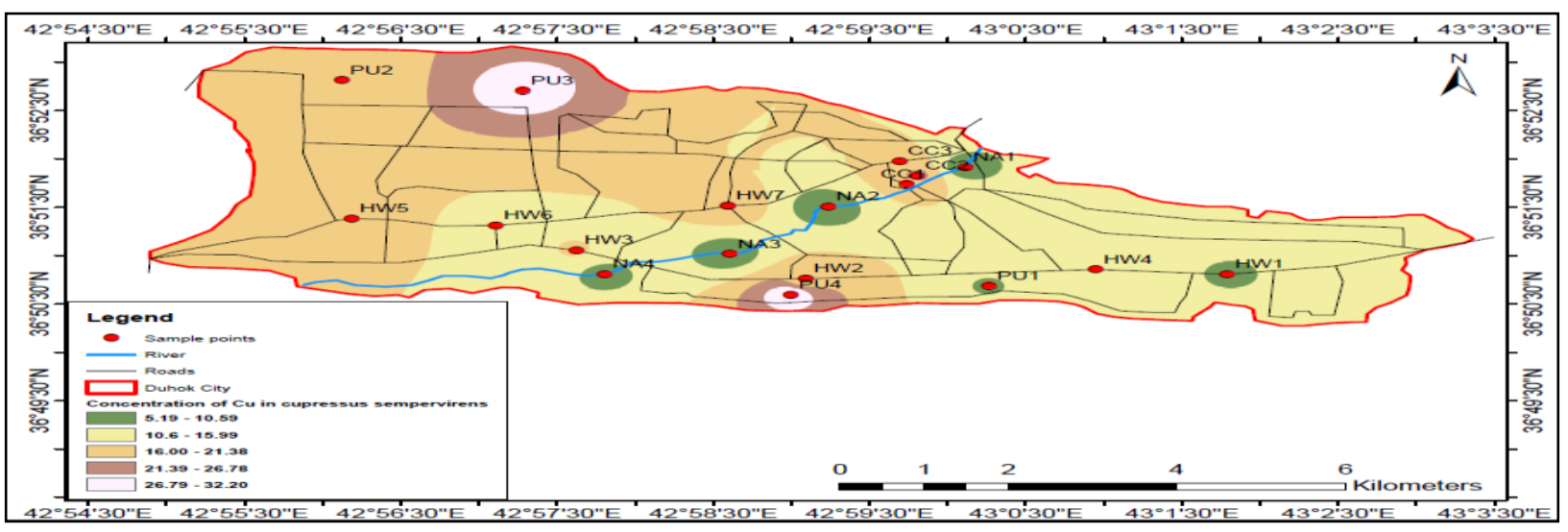

Fig. (12): The concentration of $\mathrm{Cu}$ in C. semprevirens

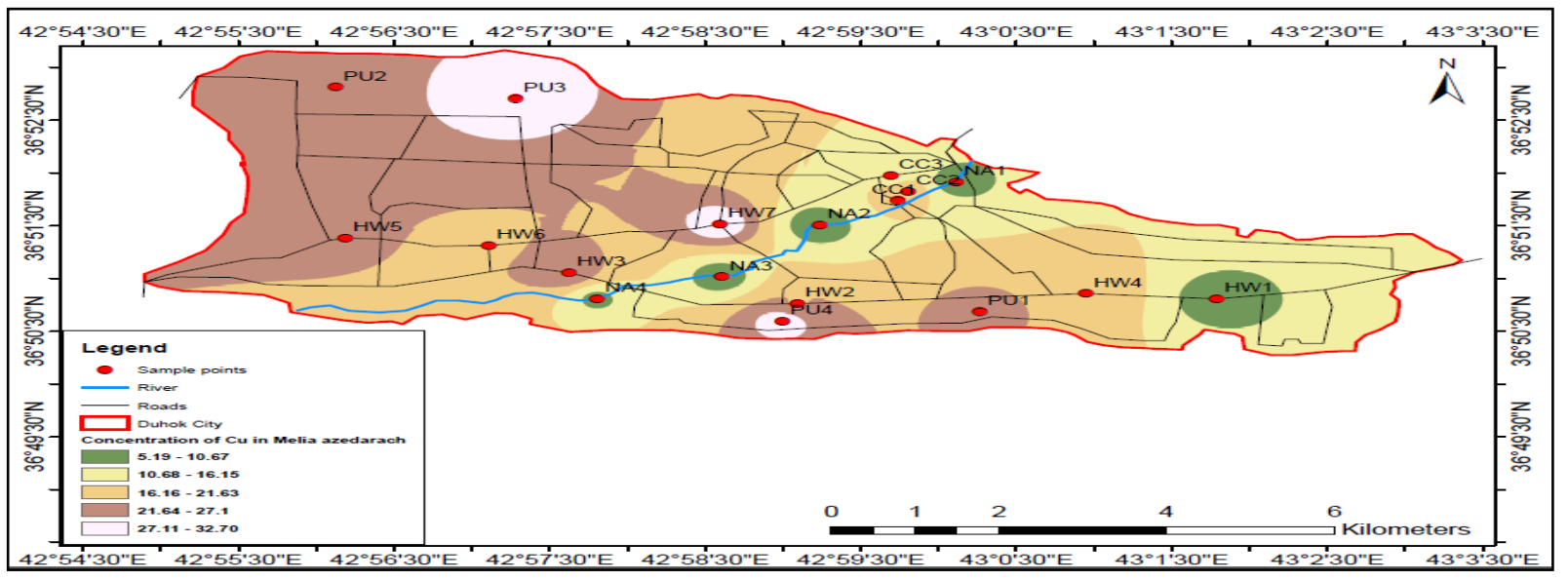

Fig. (13): The concentration of $\mathrm{Cu}$ in M. azedarach. 
$\mathrm{Cu}$ outcomes indicated, the highest value of $\mathrm{Cu}$ buildup presented in $\mathrm{M}$. azedarach with 28.567 mg.kg- ${ }^{-1}$; subsequent by $C$. sempervirens and $P$. brutia with 22.43 and 22.15 mg.kg ${ }^{-1}$ respectively. Likewise, all of the listed high values site in Peri-urban such results are represented in Figures (11, 12 and 13). However, the findings of the current study do not support the previous research results of Onder et al, (2007); Kuklová et al., (2019) who found the uppermost value of $\mathrm{Cu}$ along with $\mathrm{Pb}$ and $\mathrm{Cd}$ at urban roadsides.

\section{CONCLUSION}

The results presented here may facilitate improvements in better knowledge of air pollution situation in Duhok City. By using GIS technique with (IDW) interpolation, the city center and highway find to be the most polluted categories in the city, while the peri-urban followed by control area are characterized by low contamination rates. More samples in different areas and different timing for future researches are recommended.

\section{REFERENCESES}

Aksoy, A., Şahin, U. and Duman, F., (2000). Robinia pseudo-acacia L. as a possible biomonitor of heavy metal pollution in Kayseri. Turkish Journal of Botany, 24(5), 279-284.

Albeyboni, D., \& Youssef, S. (2019). Assessing the heavy metals bioaccumulation of Pinus brutia ten. urban tree in Duhok, Kurdistan region of Iraq. Journal of Duhok University, 22(1), 332346.

Bakirdere, S., \&Yaman, M. (2008). Determination of lead, cadmium and copper in roadside soil and plants in Elazig, Turkey. Environmental Monitoring and Assessment, 136(1-3), 401410.

Banja M., E. Como, B. Murtaj, A.Zotaj A. (2010). Mapping air Pollution in urban Tirana area using GIS. International Conference SDI. 15:105-114

Bozdogan, E., 2016. Heavy metal concentration in leaves of Melia azedarach as a biomonitor of traffic-related air pollution. Oxid. Communic, 39, 756-764.

Cassidy, T., G. Inglis, C. Wiysonge, and R. Matzopoulos. (2014). A systematic review of the effects of poverty deconcentration and urban upgrading on youth violence. Health Place 26:78-87.

Celik, A., Kartal, A. A., Akdoğan, A., \&Kaska, Y. (2005). Determining the heavy metal pollution in Denizli (Turkey) by using Robinio pseudoacacia L. Environment International, 31(1), 105-112.

Dogan, Y., Ugulu, I., \& Baslar, S. (2010). Turkish Red Pine as a biomonitor: A comparative study of the accumulation of trace elements in the needles and bark. Ekoloji, 19(75), 88-96.

Duh, J.-D., V. Shandas, H. Chang, and L.A. George. (2008). Rates of urbanisation and the resiliency of air and water quality. Sci. Total Environ. 400(1-3): 238-56.

El-Hasan, T., Al-Omari, H., Jiries, A., \& Al-Nasir, F. (2002). Cypress tree (Cupressus semervirens L.) bark as an indicator for heavy metal pollution in the atmosphere of Amman City, Jordan. Environment International, 28(6), 513519.

ESRI (1999). Getting started with ArcGIS. USA. 260 $\mathrm{p}$

Gerdol, R., Marchesini, R., Iacumin, P., \&Brancaleoni, L. (2014). Monitoring temporal trends of air pollution in an urban area using mosses and lichens as biomonitors. Chemosphere, 108, 388-395.

Gouri S.B, K.S. Pravat, Ramkrishna M. (2018). Comparison of GIS-based interpolation methods for spatial distribution of soil organic carbon (SOC), J. Saudi Soc. Agric. Sci. 17: 114-126.

Hassan R. A., (2012). Evaluation of the Effect of Vehicle Exhaust Emission on the Ambient Air Quality in Duhok City. MSC. Faculty of Engineering and Applied Science, School of Planning. Duhok. Iraq.

Hu, R., Yan, Y., Zhou, X., Wang, Y., \& Fang, Y. (2018). Monitoring heavy metal contents with Sphagnum junghuhnianum moss bags in relation to traffic volume in Wuxi, China. International journal of environmental research and public health, 15(2), 374.

Huff, G., and L. Angeles. 2011. Globalization, industrialization and urbanization in pre-World War II Southeast Asia. Explor. Econ. Hist. 48(1): 20-36.

Jerrett M, A. Arain, PK. anaroglou, B. Beckerman, D. Potoglou, T. Sahsuvaroglu, J. Morrison and Giovis C. (2005). A review and evaluation of 
intraurban air pollution exposure models. J. of Exposure science\&amp; Environmental Epidemiology. 15, pages185-204.

Kabata-Pendias, A., \&Pendias, H. (2001). Trace Elements in Soils and Plants Third Edition (Third edition). Boca: CRC Press.

Khan, S., Khan, M. A., \& Rehman, S. (2011). Lead and Cadmium Contamination of Different Roadside Soils and Plants in Peshawar City, Pakistan. Pedosphere, 21(3), 351-357.

Kuklová, M., Hniličková, H., Hnilička, F., Pivková, I., \&Kukla, J. (2019). Impact of expressway on physiology of plants and accumulation of risk elements in forest ecosystems. Plant, Soil and Environment, 65(1), 46-53.

Kumar, A., Gupta, I., Brandt, J., Kumar, R., Dikshit, A. K., \&Patil, R. S. (2016). Air quality mapping using GIS and economic evaluation of health impact for Mumbai city, India. Journal of the Air \& Waste Management Association, 66(5), 470-481.

Martens, D. C., \& Lindsay, W. L. (1990). Testing soils for copper, iron, manganese, and zinc. Testing Soils for Copper, Iron, Manganese, and Zinc. 229-264.

Matejicek, L., (2005). Spatial Modelling of Air Pollution in Urban Areas with GIS: A Case Study on Integrated Database Development. Advances in Geosciences, 63-68.

Mishra, S., \& Pandey, R. P. (2011). Effects of air pollution on plants in urban area: A case study of Ghaziabad (UP) India, VSRD Tech. NonTech. J, 2(5), 262-266.

Mishra, S., Bharagava, R. N., More, N., Yadav, A., Zainith, S., Mani, S., \&Chowdhary, P. (2019). Heavy metal contamination: an alarming threat to environment and human health. In Environmental biotechnology: For sustainable future (pp. 103-125). Springer, Singapore.

Mohammed (2013) Land use and cover change assessment using Remote sensing and GIS: Duhok city Kurdistan, Iraq (19982011).International journal of Geomatics and Geosciences. 3(3):0976- 4380.

Mustafa and Noori (2013), Satellite remote sensing and geographic information systems (GIS) to assess changes in the water level in the Duhok dam. International Journal of Water Resources and Environmental Engineering. 5(6), pp. 351359.
Naderizadeh, Z., Khademi, H., \& Ayoubi, S. (2016). Biomonitoring of atmospheric heavy metals pollution using dust deposited on date palm leaves in southwestern Iran. Atmósfera, 29(2).

NCCIRAQ. (2015). Dohuk Governorate Profile. Retrieved online at: https://www.ncciraq.org/images/infobygov/N CCI_Dohuk_Governorate_Profile.pdf Hindav N. Habeeb and Yaseen T. Mustafa (2014). High Spatial Resolution WorldView-2 Imagery for Mapping and Classification of Tree Species in Zawita Sub-district, Duhok, Kurdistan RegionIraq. Journal of University of Duhok.

Ndiokwere, C. L. (1984). A study of heavy metal pollution from motor vehicle emissions and its effect on roadside soil, vegetation and crops in Nigeria. Environmental Pollution Series B, Chemical and Physical, 7(1), 35-42.

Onder, S, Dursun, S., Gezgin, S., \&Demirbas, A. (2007). Determination of Heavy Metal Pollution in Grass and Soil of City Centre Green Areas. 16(1), 10

Patel, R.B., and F.M. Burkle (2012). Rapid urbanization and the growing threat of violence and conflict: A 21st century crisis. Prehosp. Disaster Med. 27(2): 194-97.

Popescu, C. G. (2011). Relation between vehicle traffic and heavy metals content from the particulate matters. Romanian Reports in Physics, 63(2), 471-482.

Rajé, F., Tight, M., \& Pope, F. D. (2018). Traffic pollution: a search for solutions for a city like Nairobi. Cities, 82, 100-107.

Rodrigue, J. P., Comtois, C., \&Slack, B. (2016). The geography of transport systems. Routledge.

Sarkar, C., \& Webster, C. (2017). Urban environments and human health: current trends and future directions. Current Opinion in Environmental Sustainability, 25, 33-44.

Shinde, S. M., \&Karjinni, V. V. (2005). Impact of Vehicular Growth a Cause for Change in Air Quality of Indian Cities-A Review. Population, 2008(2015), 2025.

Singh, N., Pandey, V., Misra, J., Yunus, M., \& Ahmad, K. J. (1997). Atmospheric lead pollution from vehicular emissions-measurements in plants, soil and milk samples. Environmental Monitoring and Assessment, 45(1), 9-19.

Singh, R., Jha, A. B., Misra, A. N., \& Sharma, P. (2019). Adaption mechanisms in plants under heavy metal stress conditions during 
phytoremediation. In Phytomanagement of Polluted Sites (pp. 329-360).

Staszewski, T., Kubiesa, P., Łukasik, W., \&Zając, E. (2009). Changes in concentration of $\mathrm{Cd}$ and $\mathrm{Pb}$ in soil of Pieniński National Park. Mendelova Zemědělská a Lesnická Univerzita v Brně, 2(2), 11.

Świetlik, R., Strzelecka, M., \&Trojanowska, M. (2013). Evaluation of traffic-related heavy metals emissions using noise barrier road dust analysis. Polish Journal of Environmental Studies, 22(2), 561-567.

United States Office of Air Quality. (2007). Metals Risk Assessment, EPA 120/R-07/001, 3-21-29.
Yerramilli, A., Dodla, V. B. R., \&Yerramilli, S. (2011). Air pollution, modeling and GIS based decision support systems for air quality risk assessment. Advance air pollution, 295-324.

Yilmaz G. and Y. Hocanli (2006). Mapping of noise by using GIS in Sanliurfa, Environ. Monit. Assess. 121: 103-108.

Youssef, S., Galalaey, A., Mahmood, A., Mahdi, H., \& Véla, E. (2019). Wild orchids of the Kurdistan Region areas: a scientific window on the unexpected nature of the North-Western Zagros.

\section{ويّنهكرنا نه خشهييّن (نهخشهرنا, ويّنه كرنا) ييس بوونا كانزاييّن قورس ل دهثهريّ شارستانى ب ريّكا

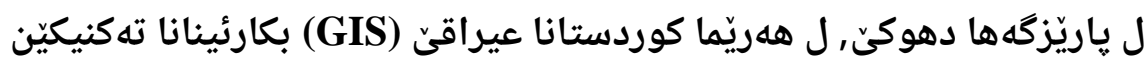

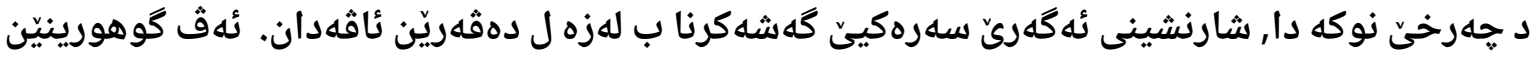

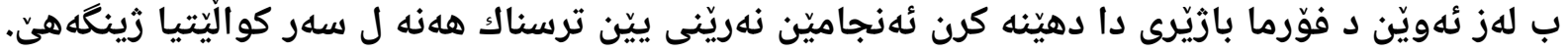

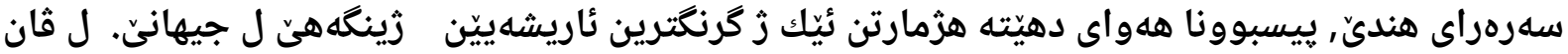
دوماهيكان دا, ئاميريّن GIS سيستهى زانيارييّن جوگرافى) ب رهنكهي كارا هه فبهش دبيت د

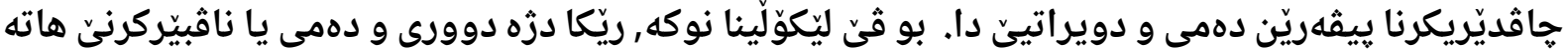

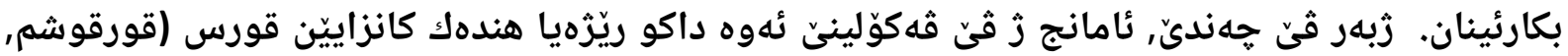

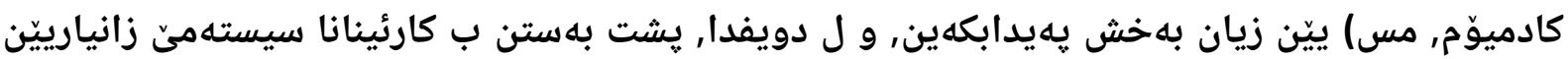
جوكرافى, نافبيّركرن د جينيّن جودا جودا ييّن بازيّرى دا هاتنه دهستنيشان كرن. ئهنجامان نيشان دان دا كو دهثهريّن كونتروّل كيّمترين ريّزهيا كانزايان تيّدا ههيه , و لديقدا جهيّين دهوروبهريّن بازيّرى د هيّن, و ههروهسا

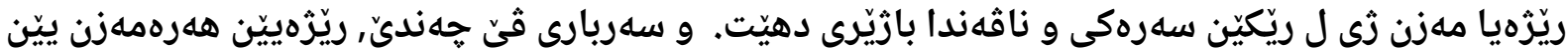
ييسبوونا كانزاييّن قورس هاتنه ديتن ل وان جهيّن قهرهبالغا ترومبيّلان ليّ ههى و يرانيا وان جهان زي رهخيّن جادهيان بوون. د ئهنجام دا, بلندترين ريّزهييّن ييسبوونى ب كانزاييّن قورس ديار بوون ل وان جهيّن قهرهبالغا ترومبيّلان ليّ هلى و به هرا يتر زى ل بهر رهخيّن ريّكان.

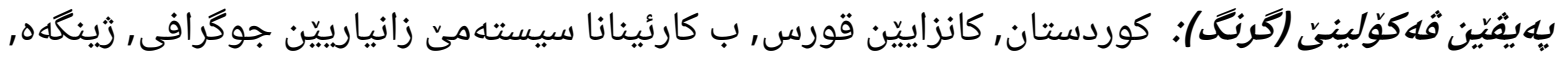
نموونهييّن تايبهت, دهفهريّن شارستانى, يِيسبوونا ههواى دوريتي 
استخدام تقنيات نظم المعلومات الجغرافية في خريطة التلوث المعادن الثقيلة للمناطق الحضرية في محافظة دهوك

الخلاصة

في القرن الحالي ، يعد التوسع العمراني هو السبب الرئيسي للنمو السريع في المناطق الحضرية. هذه التغيرات السريعة في الشكل الحضري لها عواقب سلبية خطيرة على جودة البيئة. علاوة على ذلك ، يعتبر

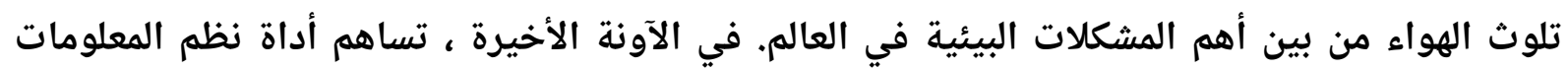

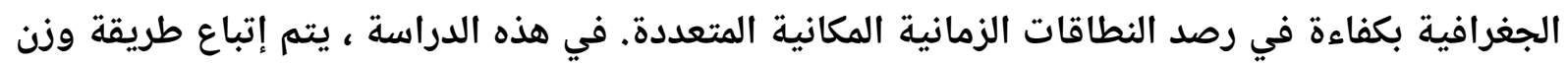
المسافة العكسية للاستيفاء. وبالتالي ، فإن الهدف من هذه الدراسة هو العثور على معدل بعض المعادن الثقيلة الخطيرة Pb و Cd و Cu و اعتمادًا على تطبيق GIS ، تم تحديد التداخلات في فئات المختلفة داخل المدينة.

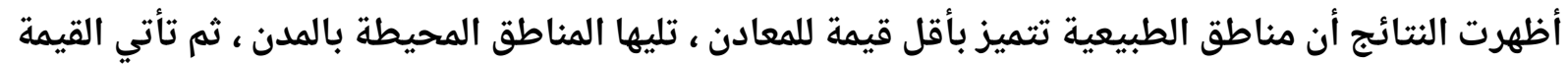

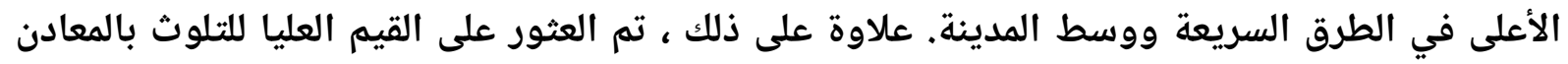

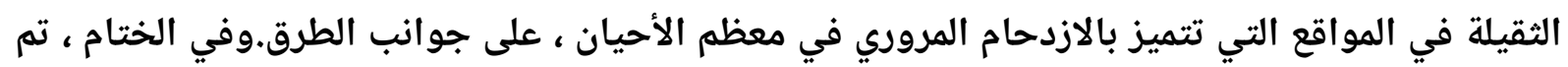

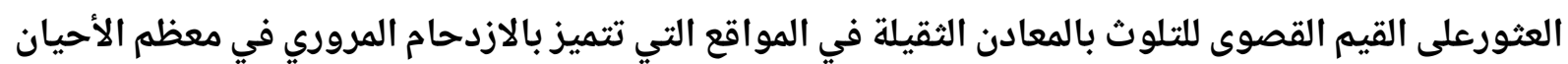

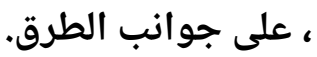

